\title{
The effect of drought on dissolved organic carbon (DOC) release from peatland soil and vegetation sources
}

\author{
Jonathan P. Ritson ${ }^{1, *}$, Richard E. Brazier ${ }^{2}$, Nigel J. D. Graham ${ }^{1}$, Chris Freeman ${ }^{3}$, Michael R. Templeton ${ }^{1}$, and \\ Joanna M. Clark ${ }^{4}$ \\ ${ }^{1}$ Department of Civil and Environmental Engineering, Imperial College London, South Kensington, London, SW7 2AZ, UK \\ ${ }^{2}$ Geography, College of Life and Environmental Sciences, University of Exeter, Exeter, EX4 4RJ, UK \\ ${ }^{3}$ Wolfson Carbon Capture Laboratory, School of Biological Sciences, Bangor University, Bangor, Gwynedd, LL57 2UW, UK \\ ${ }^{4}$ Department of Geography and Environmental Science, School of Archaeology, Geography and Environmental Science, \\ the University of Reading, Whiteknights campus, P.O. Box 227, Reading, RG6 6AB, UK \\ * Invited contribution by Jonathan P. Ritson, recipient of the EGU Biogeosciences Outstanding Student Poster Award 2015.
}

Correspondence to: Jonathan P. Ritson (j.ritson12@imprerial.ac.uk)

Received: 28 November 2016 - Discussion started: 12 January 2017

Revised: 5 May 2017 - Accepted: 8 May 2017 - Published: 16 June 2017

\begin{abstract}
Drought conditions are expected to increase in frequency and severity as the climate changes, representing a threat to carbon sequestered in peat soils. Downstream water treatment works are also at risk of regulatory compliance failures and higher treatment costs due to the increase in riverine dissolved organic carbon (DOC) often observed after droughts. More frequent droughts may also shift dominant vegetation in peatlands from Sphagnum moss to more drought-tolerant species. This paper examines the impact of drought on the production and treatability of DOC from four vegetation litters (Calluna vulgaris, Juncus effusus, Molinia caerulea and Sphagnum spp.) and a peat soil. We found that mild droughts caused a $39.6 \%$ increase in DOC production from peat and that peat DOC that had been exposed to oxygen was harder to remove by conventional water treatment processes (coagulation/flocculation). Drought had no effect on the amount of DOC production from vegetation litters; however large variation was observed between typical peatland species (Sphagnum and Calluna) and drought-tolerant grassland species (Juncus and Molinia), with the latter producing more DOC per unit weight. This would therefore suggest the increase in riverine DOC often observed postdrought is due entirely to soil microbial processes and DOC solubility rather than litter layer effects. Long-term shifts in species diversity may, therefore, be the most important impact of drought on litter layer DOC flux, whereas pulses related to drought may be observed in peat soils and are likely to become more common in the future. These results pro-
\end{abstract}

vide evidence in support of catchment management which increases the resilience of peat soils to drought, such as ditch blocking to raise water tables.

\section{Introduction}

Organic-rich peat soils are a major global carbon (C) sink (Limpens et al., 2008) which have formed due to the limited decay of recalcitrant plant litter found in peatland areas, coupled with anoxic conditions created by high water tables slowing decay (Billett et al., 2010; van Breemen, 1995). The extent to which conditions favourable to peat formation exist is threatened by climate change (Clark et al., 2010; GallegoSala and Prentice, 2012), and altered precipitation patterns and more frequent droughts may destabilise sequestered $\mathrm{C}$ (Evans and Warburton, 2010; Fenner and Freeman, 2011; Freeman et al., 2001).

Dissolved organic carbon (DOC) represents a significant flux of carbon from peatlands at around $24 \%$ of net ecosystem exchange $C$ uptake (Dinsmore et al., 2010) and can also lead to difficulties for downstream drinking water treatment plants. DOC can cause colour, odour and taste problems in drinking water and so must be removed as best as possible during treatment, commonly by coagulation, flocculation and sedimentation/flotation. Any DOC which remains may act as a substrate for microbial growth in the distribution system (Rodriguez and Sérodes, 2001) and can react during disinfec- 
tion to form disinfection by-products (DBPs) (Rook, 1974) which may have human health implications due to their potential genotoxicity and carcinogenicity (Nieuwenhuijsen et al., 2009).

Droughts are projected to become more common under future climate conditions in the UK (Jenkins et al., 2009). Droughts can have drastic consequences for peatland $\mathrm{C}$ storage and riverine DOC concentrations due to the "enzymaticlatch" mechanism, whereby decomposition is suppressed due to the inhibitory effect of phenolic compounds. Under drought conditions, the water table is lowered, creating oxic conditions which stimulate phenol oxidase enzymes, thereby reducing the concentration of phenolics and their inhibitory effect on hydrolase enzymes (Fenner and Freeman, 2011; Freeman et al., 2001). Altered redox conditions can also change the controls on DOC solubility, meaning organic C is not solubilised during the drought but instead flushed from the system once redox conditions return to normal (Clark et al., 2006, 2005, 2011). These processes have led to numerous observations of increased riverine DOC after droughts which may remain elevated for years after the event (Evans et al., 2005; Scott et al., 1998; Watts et al., 2001; Worrall and Burt, 2004). How drought affects the treatability of dissolved organic matter (DOM) is less well understood, although some authors have noted an increase in the hydrophilic component during droughts and more hydrophobic character postdrought (Clark et al., 2011; Scott et al., 1998; Watts et al., 2001). Hydrophobic DOM is commonly regarded as being easier to remove via coagulation than the hydrophilic fraction (Bond et al., 2011; Matilainen et al., 2010).

The impact of climate change on DOC production and drinking water treatment is complex and involves a number of biogeochemical cycles (Ritson et al., 2014b). Vegetative change in peatlands has occurred in the recent past (Chambers et al., 2007b) and is projected to continue with Sphagnum mosses, which are favoured for peat formation, giving way to vascular plants (Fenner et al., 2007; Weltzin et al., 2003). Many grassland species (e.g. Juncus effusus, Molinia caerulea) have encroached on peatland areas as a result of anthropogenic pressures such as nutrient deposition and management practices (Berendse, 1994; Chambers et al., 2007a; McCorry and Renou, 2003; Shaw et al., 1996). These species are adapted to higher nutrient availability (Aerts, 1999) and thus can outcompete peatland species if nutrient levels are elevated through, for example, nitrogen deposition (Berendse et al., 2001). Their rooting systems are also commonly deeper and more extensive than upland plant species, facilitating colonisation of peatland areas with fluctuating water tables (Lazenby, 1955; Loach, 1968). Our previous work (Ritson et al., 2016) has also shown that Juncus and Molinia may create an increase in the speed and seasonality of $\mathrm{C}$ cycling in peatland litter layers due to their annual cycle of production of a large amount of relatively labile aboveground biomass.
Vegetative change has implications for $\mathrm{C}$ storage in peatlands, as Sphagnum is responsible for a number of mechanisms (e.g. the production of recalcitrant litter) which allow C to be stored over long time periods (van Breemen, 1995). Conversely, many vascular plants can destabilise colonised peat, stimulating decomposition by adding labile $\mathrm{C}$ at the surface and through their root systems (Fenner et al., 2007; Gogo et al., 2010). As such, a number of programmes have aimed to promote Sphagnum dominance for $\mathrm{C}$ storage and other ecosystem services by blocking drainage ditches to re-establish high water tables (Grand-Clement et al., 2013). So far preliminary results from ditch-blocking schemes have shown a shift to vegetation species suited to wet conditions and a decrease in peak flows in the restored catchment, leading to a decrease in DOC load as concentration has remained the same (Luscombe et al., 2014; Smith et al., 2014). Further evidence is needed on the water quality outcomes of such interventions and the implications for water treatment as the timescales of restoration ( $<5$ years) are short compared to both the period of drainage (typically $10-100$ years) and the period of peat formation (thousands of years).

Previous work has highlighted both the vegetative source and climate controls on production affecting the ease of removal of DOC and the formation of DBPs (Gough et al., 2012; Reckhow et al., 2007; Ritson et al., 2014a; Tang et al., 2013). The present research sought to build on the work of Ritson et al. (2016) by assessing the effect of oxygenation of peat and vegetation due to drought on peatland DOC flux and any interaction with projected changes in litter input. The previous study had only assessed the DOC quality differences between sources collected from the field with minimal degradation/oxygenation. To this end, climate simulations of varying drought severities defined in terms of percentiles of mean monthly rainfall were performed on four typical peatland vegetation types (Calluna vulgaris, Juncus effusus, Molinia caerulea and Sphagnum spp.) and a peat soil. After a 6-week drought simulation, the DOC released upon rewetting was analysed in terms of optical properties and coagulation removal efficiency with ferric sulfate to determine (a) whether drought conditions affect DOC production from peatland litter and soil types and (b) whether the differences in litter quality identified in Ritson et al. (2016) between typical peatland vegetation (Sphagnum spp. and Calluna vulgaris) and invasive, drought-tolerant vegetation (Molinia and Juncus) cause different responses to drought in terms of DOC production (i.e. an interaction between the vegetation source and drought condition).

\section{Methodology}

\subsection{Field site and sample collection}

Samples were collected from the Spooners site $\left(51^{\circ} 07^{\prime} 23.3^{\prime \prime} \mathrm{N}, 3^{\circ} 45^{\prime} 11.8^{\prime \prime} \mathrm{W}\right)$ in Exmoor National Park, 
UK, at approximately $400 \mathrm{~m}$ elevation. Further site details can be found in Ritson et al. (2014a). The site is part of the Mires project (Arnott, 2010) and was chosen as this area has been highlighted as a marginal peatland which may be vulnerable to climate change (Clark et al., 2010).

Samples of vegetation and peat soil were collected in one day in May 2014, sealed in airtight bags in a chilled container for transport from the field and stored in the dark at $4^{\circ} \mathrm{C}$ before use. For vascular plants, litter was collected as standing dead biomass. As the decomposition of Sphagnum is a continuum process, the section $2-4 \mathrm{~cm}$ below the capitulum was taken as equivalent to freshly senesced "litter", as in other studies (e.g. Bragazza et al., 2007). Samples were sorted to remove any vegetation not belonging to the target species and then cut to $2 \mathrm{~cm}$ length and homogenised. Peat samples were collected using a screw auger, and peat from $10-30 \mathrm{~cm}$ depth was used in the experiments. Peat samples were sorted to remove as many roots as possible, but in sites where Molinia was present some fine roots remained.

The start times of the drought simulations for different DOC sources were staggered by up to 2 weeks to allow prompt analysis of water extracts at the end of the experiments. Preliminary work suggested chilled storage gave no significant difference in the amount of water-extractable DOC or UV absorbance properties after 3 weeks of storage in the dark at $4{ }^{\circ} \mathrm{C}$.

\subsection{Experimental design}

The vegetation and peat samples were homogenised by hand and randomly assigned a drought treatment in a five (vegetation types) $\times$ four (drought treatments) design with five replicates per treatment, giving 100 samples in total. Similar experiments concerning the decomposition of litter have used three replicates per treatment (Fellman et al., 2013; Soong et al., 2015), suggesting our approach of using five samples per treatment is adequate to capture variability between samples.

Data were obtained from regional historic climate records of the UK Meteorological Office for the south-west of England for the period 1910-2013 (UK Met Office 2014), and these values were used to define three severities of drought and a control value. Data for the months of June, July and August (310 months in total) were used to find the 50th, 25th, 10th and 5th percentile for total monthly rainfall, and these values have been used to set monthly rainfall values for control $(79.0 \mathrm{~mm}$ ), mild (51.5), moderate (34.7) and severe droughts (23.3), respectively.

The number of days of rain per month was fixed at a baseline value of 11 (regional average for June, July and August), and temperature ranged between the mean daily maximum of $18.9^{\circ} \mathrm{C}$ for $12 \mathrm{~h}$ and the mean daily minimum of $10.7^{\circ} \mathrm{C}$ for $12 \mathrm{~h}$, calculated using the same historical UK Meteorological Office datasets for the south-west of England.

\subsection{Experimental procedure and laboratory methods}

As in other decomposition studies, vegetation samples were air-dried to constant weight and then mixed before subsampling (e.g. Latter et al., 1998). Five subsamples of each vegetation type were then oven-dried at $70^{\circ} \mathrm{C}$ until constant weight to determine the air-dry-to-oven-dry conversion factor. The peat samples were not air-dried before use as this would have changed the redox conditions within the peat and created a hydrophobic layer, which can cause problems for rewetting (Worrall et al., 2003). This will mean less accuracy in determining the starting weight of the peat sample as some variation in water content may exist; however this was minimised by effective homogenisation. Elemental analysis on a subsample of the starting material revealed $\mathrm{C}: \mathrm{N}$ to be in the order peat (29.9), Molinia (35.7), Juncus (42.2), Calluna (56.5) and Sphagnum (93.7) as reported in Ritson et al. (2016).

Buchner funnels fitted into amber-glass bottles were used to hold the sample and collect the simulated rainfall. Approximately $2 \mathrm{~g}$ dry weight of air-dried vegetation/peat was used; however a lower weight of sample was used for Sphagnum $(\sim 0.65 \mathrm{~g})$ and Molinia $(\sim 1.5 \mathrm{~g})$ as this was enough to fill the Buchner funnel. The peat samples were spread over the area of the funnel so that a seal was created, and the simulated rainwater infiltrated the peat rather than draining directly into the funnel.

The samples were then placed in an incubator for 6 weeks, with simulated rainfall applied 11 times per month at regular intervals using high-purity reverse osmosis (RO)-treated water, following the methodology of Ritson et al. (2016). Data on final water weight, available in the Supplement, confirm degrees of desiccation between the treatments. RO or deionised water has been used in similar degradation studies (Cortez et al., 1996; Soong et al., 2014); it is employed so that no organic carbon is added to the samples and for the extraction step is considered to be representative of soil solutions collected in situ (Chantigny et al., 2007).

As the samples were collected from the field and had been in contact with litter and soil, no inoculation with microorganisms was required as a suitable decomposer community was likely to be present (Van Meeteren et al., 2007). In this experiment the action of invertebrates and other microfauna was excluded; however their role in the decay of peatland litter is minimal (Dickinson and Maggs, 1974), although their role in DOC production from peat soils may be more significant (Cole et al., 2002).

At the end of the 6-week simulation the samples were air-dried and weighed. Water-extractable DOC from the airdried sample was taken to simulate rewetting following the end of the drought. DOC was extracted from soil and vegetation samples using an approximately $20: 1$ ratio of ROtreated water to sample. The samples were then filtered with pre-ashed GF/F filters (Whatman), and the $\mathrm{pH}$ was measured. Previous work has shown that the amount of water used to 
extract DOC and whether one extraction is performed or sequential extractions are performed to simulate multiple rainfall events give no significant variation in DOC quality, only changes in the total amount of C (Don and Kalbitz, 2005; Soong et al., 2014). DOC was measured as non-purgeable organic carbon (NPOC) via a UV/persulfate oxidation method on a Shimadzu TOC-V instrument. The method detection limit was determined by running five blank samples and using the value of 3 times the standard deviation. This was found to be $0.05 \mathrm{mgC} \mathrm{L}^{-1}$.

$\mathrm{UV}$ and fluorescence analysis was undertaken before coagulation/flocculation jar testing. UV absorbance was measured on a Perkin Elmer LAMBDA 3 using a $1 \mathrm{~cm}$ pathlength quartz cuvette, and the specific ultraviolet absorbance, SUVA, was calculated as the absorbance at $254 \mathrm{~nm}$ in units of $\mathrm{m}^{-1}$ divided by the NPOC content $\left(\mathrm{mg} \mathrm{C} \mathrm{L}^{-1}\right)$.

Fluorescence analysis was completed using a Vary Eclipse fluorescence spectrophotometer, where samples were scanned at excitation wavelengths between 220 and $450 \mathrm{~nm}$ at $5 \mathrm{~nm}$ intervals and the resulting emission recorded between 300 and $600 \mathrm{~nm}$ at $2 \mathrm{~nm}$ intervals. An R script was produced based on existing scripts (Lapworth and Kinniburgh, 2009) which performed a blank subtraction, masked out Rayleigh and Raman scattering, visualised the data and calculated fluorescence indices. Data were normalised to the Raman scattering peak of a RO water sample to allow comparison to other laboratories (Lawaetz and Stedmon, 2009). The "peak-C" measure, related to humic-like character, and the tryptophan-like peak, "peak T", were defined as in Beggs et al. (2013).

Coagulation was performed on $350 \mathrm{~mL}$ of sample diluted to $3 \mathrm{mg} \mathrm{L}^{-1}$ DOC using a Phipps and Bird PB-700 paddled jar tester (Phipps and Bird Ltd., Virginia, USA). After settling, the sample was filtered by Whatman qualitative grade 2 filters to remove flocs before NPOC analysis. Preliminary work indicated the following conditions gave effective DOC removal of similar samples: $\mathrm{pH} 5.5,30.0 \mathrm{mg} \mathrm{L}^{-1}$ ferric sulfate dosed with $28.5 \mathrm{mg} \mathrm{L}^{-1}$ calcium hydroxide for $\mathrm{pH}$ control during a flash mix of $1 \mathrm{~min}$ at $175 \mathrm{rpm}$, followed by a slow mix of $30 \mathrm{~min}$ at $60 \mathrm{rpm}$ and then $1 \mathrm{~h}$ of settling. Assessment of DBP formation was attempted; however analysis within the 2-week period specified in the method was not possible due to instrument failure, so data quality could not be assured.

\subsection{Data analysis and statistical methods}

Statistical analysis was performed in the open-source programming language $\mathrm{R}$ and SPSS version 21 (IBM). Due to problems with normality and heteroscedasticity, a Box-Cox transform (Box and Cox, 1964) was applied to the variables before testing with a factorial ANOVA. A Tukey honest significant difference (HSD) post hoc procedure was used for pairwise comparisons between the DOC sources and drought conditions. Estimates of effect sizes were made using $\omega^{2}$ as this is suitable for small sample sizes (Keselman, 1975). Interactive effects from the omnibus ANOVA were followed up using multiple one-way ANOVAs with a Holm-Šidák correction to control the inflation of type one error (Holm, 1979; Šidák, 1967). This method changes the value used for alpha, the significance level, based on how many comparisons have been performed starting with the source with lowest $p$ value and moving to the next lowest until an insignificant comparison is found. Correlations between variables were tested using Spearman's $\rho$ test (Spearman, 1904), and differences between the start and end of the repetition of the control group were tested using Student's $t$ test and Levene's test for equal variance (Levene, 1960; Student, 1908).

\subsection{Repetition of the control group conditions}

To further investigate the effect of oxygenation of peat on DOC production and treatability, the control condition of this experiment was repeated in August 2015 using peat samples collected from similar ombrotrophic peatland sites in Dartmoor National Park (site details available in Ritson et al., 2016). Water-extractable DOC was taken from a subsample before the climate simulation began and analysed for fluorescence and UV properties. Approximately $3.5 \mathrm{~g}$ dry weight of peat was then incubated using the same temperature and rainfall as the control samples of the drought experiment with three replicates. After 6 weeks water-extractable DOC was again taken for fluorescence and UV analysis to assess any changes in DOC quality.

\section{Results}

\subsection{Omnibus ANOVA}

A factorial ANOVA was performed exploring the source, drought and interactive effects on DOC, SUVA, DOC removal efficiency and the removal of SUVA (Table 1). Waterextractable DOC and SUVA had significant source, drought and source-drought effects, suggesting that there is variation in the sensitivity of the sources to drought. No drought effects were observed for DOC removal or SUVA removal, although the source had strong effects on these parameters. For all significant results the effect size for the source was much greater than that for the drought treatment.

\subsection{Water-extractable DOC}

The mean DOC extracted for all samples from each source is shown in Fig. 1. The vegetation samples produced more DOC than the peat soil $\left(0.58 \pm 0.02 \mathrm{mg} \mathrm{g}^{-1}\right)$, with the peatland genera, Sphagnum and Calluna, producing $3.47 \pm 0.30$ and $6.86 \pm 0.37 \mathrm{mg} \mathrm{g}^{-1}$, respectively, whereas the grassland genera, Juncus and Molinia, produced much more at $9.21 \pm 0.62$ and $16.52 \pm 1.17 \mathrm{mg} \mathrm{g}^{-1}$, respectively. A Tukey HSD test suggested that all DOC sources have significantly 
Table 1. $p$ values from factorial ANOVA (significant values have been highlighted in bold and displayed with $\omega^{2}$ estimate of effect size in brackets).

\begin{tabular}{|c|c|c|c|c|c|c|c|c|}
\hline Variable & $\begin{array}{r}\text { Water- } \\
\text { extractable } \\
\text { DOC }\end{array}$ & $\mathrm{pH}$ & SUVA & $\begin{array}{r}\text { Peak } \\
\mathrm{C}\end{array}$ & $\begin{array}{r}\text { Peak } \\
T\end{array}$ & $\begin{array}{r}\text { Peak } \\
\mathrm{C} / \mathrm{T}\end{array}$ & $\begin{array}{r}\text { DOC } \\
\text { removal }\end{array}$ & $\begin{array}{r}\text { SUVA } \\
\text { removal }\end{array}$ \\
\hline DOC source & $\begin{array}{r}<0.001 \\
(0.945)\end{array}$ & $\begin{array}{r}<0.001 \\
(0.429)\end{array}$ & $\begin{array}{r}<0.001 \\
(0.422)\end{array}$ & $\begin{array}{r}<0.001 \\
(0.846)\end{array}$ & $\begin{array}{r}<0.001 \\
(0.675)\end{array}$ & $\begin{array}{r}<0.001 \\
(0.691)\end{array}$ & $\begin{array}{r}<0.001 \\
(0.396)\end{array}$ & $\begin{array}{r}<0.001 \\
(\mathbf{0 . 3 3 1})\end{array}$ \\
\hline Drought & $\begin{array}{r}0.007 \\
(0.004)\end{array}$ & 0.143 & $\begin{array}{r}\mathbf{0 . 0 0 7} \\
(\mathbf{0 . 0 3 4})\end{array}$ & $\begin{array}{r}<0.001 \\
(0.011)\end{array}$ & $\begin{array}{r}<0.001 \\
(0.035)\end{array}$ & 0.642 & 0.418 & 0.475 \\
\hline DOC source-drought & $\begin{array}{r}0.050 \\
(0.004)\end{array}$ & 0.157 & $\begin{array}{r}0.005 \\
(0.054)\end{array}$ & $\begin{array}{r}<0.001 \\
(0.095)\end{array}$ & $\begin{array}{r}<0.001 \\
(0.177)\end{array}$ & 0.096 & 0.234 & 0.951 \\
\hline
\end{tabular}

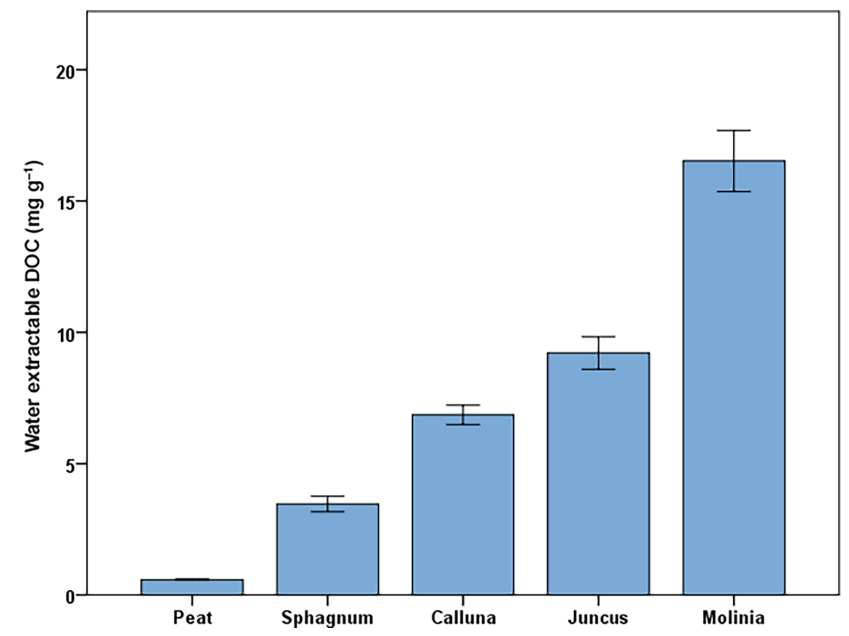

Figure 1. Water-extractable DOC of all samples across the different DOC sources $(n=20$ per source). Error bars at 1 standard error.

different means at the $p<0.01$ level except the CallunaJuncus comparison, which was significantly different at the $p<0.05$ level.

To investigate the source-drought interaction, one-way ANOVAs were performed for drought effects on each of the sources using a Holm-Šidák correction to control the inflation of type one error.

Due to the decrease in the level of significance of the $p$ value in the Holm-Šidák method, only the peat source was found to have a drought effect on water-extractable DOC $\left(p=0.010, \omega^{2}=0.393\right)$. The mean values were $0.48,0.67$, 0.61 and $0.58 \mathrm{mg} \mathrm{g}^{-1}$ for the control, mild, moderate and severe treatments of the peat DOC, respectively, and this is shown in Fig. 2. The mild drought treatment gave a significant increase in water-extractable DOC, indicated by a Tukey test for comparison to the control group $(p=0.007)$. This corresponded to a $39.6 \%$ increase in DOC production for the mild drought treatment. A larger standard error in the moderate and severe drought treatments meant that these were not significantly different from the control $(p=0.060$ and $p=0.204$, respectively).

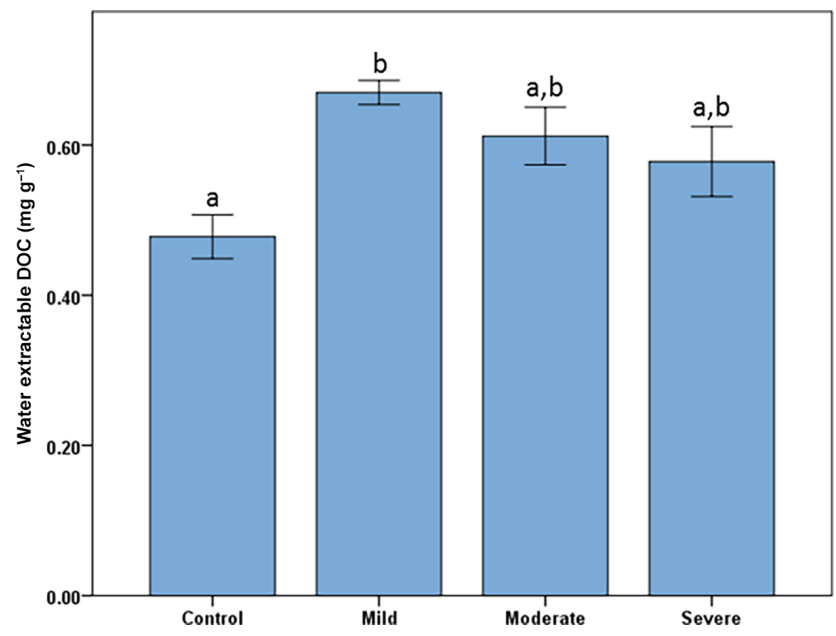

Figure 2. DOC extracted from peat on rewetting following different severities of drought ( $n=5$ per treatment). Letters indicate statistically similar groups from the Tukey test. Error bars at 1 standard error.

Variation in peat water content during the experiment was not recorded; however the water content of the peat samples was measured at the end of the experiment. This averaged $16.11,14.14,15.11$ and $5.95 \mathrm{~g}$ with standard errors of $7.7,3.0,15.9$ and $28.1 \%$ for the peat control, mild, moderate and severe drought treatments, respectively. The much larger standard error in final water content agrees with observations during the experiment, and the variation from group mean in final water content for each sample and the variation from group mean in water-extractable DOC were found to correlate (Spearman's $\rho$ coefficient 0.484 , $p=0.031)$. The source also had a significant effect (Table 1) on the $\mathrm{pH}$ of the samples, with a Tukey test suggesting three statistical subsets with peat and Calluna $<$ Calluna and Molinia < Sphagnum and Juncus. Mean values were in the order peat $(5.92 \pm 0.04)$, Calluna $(5.98 \pm 0.01)$, Molinia (6.03 \pm 0.01$)$, Sphagnum $(6.14 \pm 0.02)$ and Juncus $(6.17 \pm 0.02)$. 


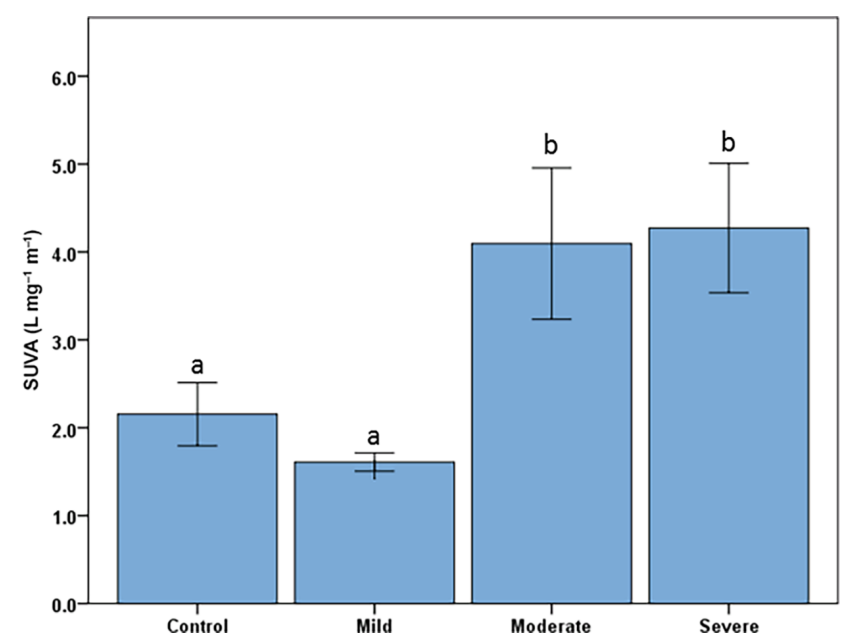

Figure 3. SUVA value of Molinia caerulea-derived DOC produced under differing severities of drought ( $n=5$ per treatment) with error bars at 1 standard error. Letters indicate statistically similar groups from the Tukey test.

\subsection{SUVA and fluorescence}

Mean values of SUVA in units of $\mathrm{L} \mathrm{mg}^{-1} \mathrm{~m}^{-1}$ for the different sources were in the order Molinia $(3.03 \pm 0.38)$, peat (3.01 \pm 0.15$)$, Juncus $(2.04 \pm 0.06)$, Calluna $(1.66 \pm 0.14)$ and then Sphagnum (1.34 \pm 0.13$)$. The Tukey HSD test suggested that the mean values for SUVA formed three subsets with peat and Molinia $>$ Calluna and Juncus $>$ Calluna and Sphagnum.

To investigate the source-drought interaction, one-way ANOVAs were performed for drought effects on SUVA from each of the sources using a Holm-Šidák correction. Only Molinia was found to have a significant drought effect on the SUVA value ( $p=0.001, \omega^{2}=0.546$ ).

Tukey's test suggested that both the moderate and severe drought treatments were significantly different than the control ( $p=0.045$ and 0.026 , respectively), with means of 2.15 , 4.09 and $4.27 \mathrm{~L} \mathrm{mg}^{-1} \mathrm{~m}^{-1}$ for the control, moderate and severe treatment of the Molinia DOC, respectively. Figure 3 shows a graph of SUVA for Molinia DOC from the different treatment groups.

The fluorescence data suggests interactive effect between drought treatments and the source of the DOC (Table 1), and these were further interrogated using the Holm-Šidák method. This suggested that there was a significant effect of drought on peak C for both Juncus ( $p<0.001, \omega^{2}=0.840$ ) and Molinia $\left(p<0.001, \omega^{2}=0.760\right)$, with the Tukey test suggesting that the severe drought treatment was significantly lower than the control $(p<0.01)$. For the peak-T fluorescence value, drought had a significant effect on Juncus DOC $\left(p<0.001, \omega^{2}=0.634\right)$, with the Tukey test suggesting that the severe drought treatment was significantly lower than the control $(p<0.01)$. The ratio of fluorescence

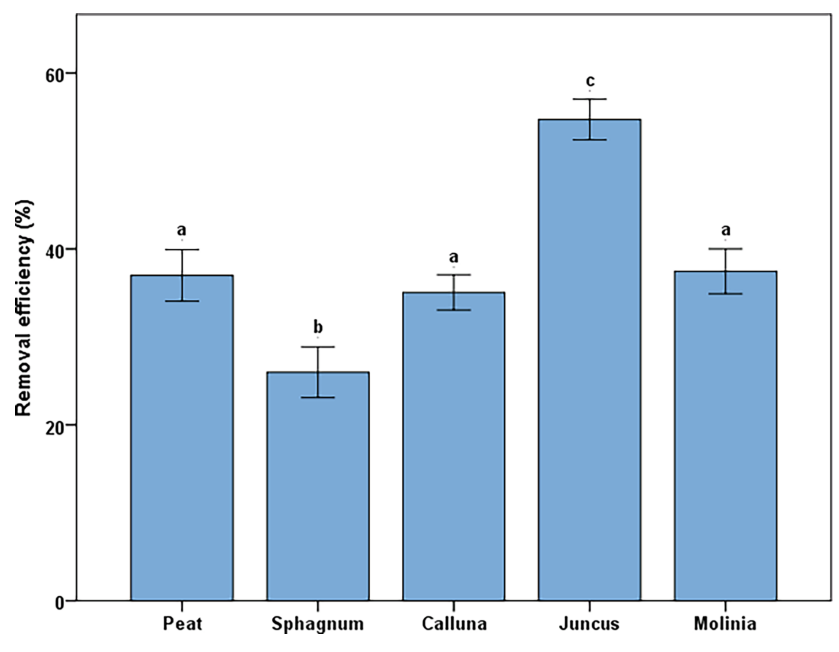

Figure 4. DOC removal efficiency by coagulation/flocculation for different DOC sources ( $n=20$ for each source) with error bars at 1 standard error. Letters indicate statistical subset according to Tukey test).

peak $\mathrm{C}$ to $\mathrm{T}$ showed no drought effect $(p>0.05)$, but there were significant differences between the sources, with a Tukey test suggesting that Sphagnum $<$ Calluna, Juncus and Molinia $<$ peat.

\subsection{DOC removal efficiency}

The factorial ANOVA suggested no drought effects on removal efficiency ( $p=0.418$ ). Mean values for DOC removal by coagulation with ferric sulfate were in the order of Juncus $(54.7 \pm 2.3 \%)$, Molinia $(37.5 \pm 2.6 \%)$, peat $(37.0 \pm 2.9 \%)$, Calluna $(35.1 \pm 2.0 \%)$ and then Sphagnum $(26.0 \pm 2.9 \%)$. The Tukey HSD test suggested that the mean values for DOC removal efficiency fell into three subsets with similar means in the order Juncus $>$ Molinia, peat and Calluna $>$ Sphagnum. The removal efficiency for all samples from each DOC source is shown in Fig. 4.

\subsection{SUVA removal efficiency}

The removal of aromaticity, measured by SUVA, is of interest in drinking water treatment as aromatic compounds have a high propensity to form some of the regulated DBPs on chlorination (Bond et al., 2011). Large, aromatic compounds are selectively removed by coagulation/flocculation, and as expected good removal $(>70 \%)$ was observed for most of the samples. The mean values for the reduction in SUVA value following coagulation with ferric sulfate was in the order of peat $(76.6 \pm 1.8 \%)$, Sphagnum $(76.3 \pm 2.5 \%)$, Molinia $(67.7 \pm 4.7 \%)$, Calluna $(49.6 \pm 5.3 \%)$ and then Juncus $(44.5 \pm 2.3 \%)$. The Tukey HSD test suggested that there were two subsets of DOC sources with similar means with peat, Sphagnum and Molinia $>$ Juncus and Calluna. 
Table 2. Spearman's $\rho$ for different DOC quality and treatability measures.

\begin{tabular}{llr}
\hline DOC quality measure & Treatability measure & Spearman's $\rho$ \\
\hline Fluorescence peak C & DOC removal \% & $0.578, p<0.001$ \\
Fluorescence peak C / T & DOC removal \% & $0.268, p=0.007$ \\
SUVA & SUVA removal \% & $0.445, p<0.001$ \\
Specific fluorescence peak C & SUVA removal \% & $0.235, p=0.019$ \\
\hline
\end{tabular}

As with the overall DOC removal efficiency, there were no drought effects on SUVA removal ( $p=0.475$ ).

\subsection{Correlations between measures of DOC quality and treatability}

A number of DOC quality indices based on absorbance and fluorescence measures were tested. The correlation coefficients for the different quality and treatability parameters are shown in Table 2. Peak C, a humic-like fluorescence peak, showed the best correlation with DOC removal efficiency, while the ratio of humic-like to protein-like fluorescence (peak C / T) gave a lower but still significant correlation coefficient. The magnitude of peak-C values is in the order Juncus $>$ Molinia $>$ Calluna $>$ peat $>$ Sphagnum, which is consistent with data on DOC removal efficiency. The SUVA value showed the best correlation with SUVA removal efficiency, suggesting that DOM with a lower proportion of aromatic compounds (low SUVA value) contains aromatic compounds which are harder to remove by coagulation, possibly meaning they are of low molecular weight and/or contain hydrophilic groups.

\subsection{Repetition of the control group conditions}

The data obtained from DOC extracted before and after the repeated simulation were analysed using Student's $t$ test (equal variances assumed, confirmed using Levene's test) to assess whether the DOC extracted was significantly different following 6 weeks of exposure to oxygen without any experimental treatment. The results of this analysis are shown in Table 3.

Water-extractable DOC increased significantly from 0.19 to $0.27 \mathrm{mg} \mathrm{g}^{-1}$, an increase of $41.6 \%$. The SUVA value decreased at the end of the simulation from 3.62 to $2.85 \mathrm{~L} \mathrm{mg} \mathrm{m}^{-1}$, as did the fluorescence peak-C measure, which suggests a decrease in the level of aromaticity and humification of the DOM, respectively. This result may explain why poorer DOC removal for peat DOC was observed in this experiment than in our previous work (Ritson et al., 2016) as exposure to oxygen reduces the aromaticity of peat DOM and therefore its amenability to removal via coagulation.
Table 3. $t$ tests for pre- and post-incubation peat samples (significant differences highlighted in bold).

\begin{tabular}{lrrr}
\hline Variable & $t$ test & $p$ value & \% change \\
\hline Extractable DOC & $\mathbf{5 . 6 8 5}$ & $\mathbf{0 . 0 0 5}$ & $\mathbf{+ 4 1 . 6}$ \\
Fluorescence peak C & $\mathbf{8 . 1 6 8}$ & $\mathbf{0 . 0 1 1}$ & $\mathbf{- 2 9 . 2}$ \\
Fluorescence C / T & 0.180 & 0.866 & Nor significant \\
SUVA & $\mathbf{3 . 1 9 5}$ & $\mathbf{0 . 0 3 3}$ & $\mathbf{- 2 3 . 0}$ \\
\hline
\end{tabular}

\section{Discussion}

\subsection{Water-extractable DOC}

Taken together, the main effects and interaction $\omega^{2}$ values suggest that the source of DOC is the most important factor on water-extractable DOC and that the effect of drought is significant only for the peat soil and not for the vegetation. The peat soil was affected by the drought treatment with higher water-extractable DOC observed at the mild severity. This finding is consistent with the enzymatic-latch hypothesis that increased oxygenation of peat engages a biogeochemical cascade whereby increased phenol oxidase activity ends the phenol-induced inhibition of hydrolase enzymes, thus increasing overall organic matter decomposition (Freeman et al., 2001). This is also confirmed by the replication of the control treatment which showed exposure to oxygen even in the absence of drought increased water-extractable DOC and decreased DOM aromaticity. This finding has implications for all laboratory studies which remove peat from anoxic conditions as these may not be representative of in situ conditions.

No effect was observed with the moderate and severe drought treatments, which may be explained by water scarcity limiting microbial activity (Toberman et al., 2008) and/or increased hydrophobic protection decreasing the water-extractable DOC on rewetting. Observations made throughout the experiment suggested that in the severe treatment there was a large variation in the extent to which each replicate dried out. Once peat becomes dry, a hydrophobic layer forms (Spaccini et al., 2002; Worrall et al., 2003), meaning that less water will infiltrate the sample, therefore possibly increasing the severity of the drought beyond the experimental design. The very low final water content of the severe treatment and observations of drying out and shrinkage of the peat mass throughout the experiment add weight to these possible explanations, although actual rates of microbial respiration were not monitored during the experiment. The correlation between variance in final water content and water-extractable DOC also suggests the source of variance may be either the application of rainfall or the extent to which each sample dried out. Although hydrophobic protection may limit DOC concentrations on rewetting, in the longer term the effect of oxygenation, described by the enzymatic-latch 
mechanism, will likely mean higher DOC production (Freeman et al., 2001).

The lack of a drought effect on DOC production from any of the vegetation types suggests the pulse in DOC observed post-drought elsewhere in catchment scale studies (Evans et al., 2005; Scott et al., 1998; Watts et al., 2001; Worrall and Burt, 2004) is likely to be due to the oxygenation of peat soils rather than any litter layer effects. Although there was no drought effect, the increase in peat-derived DOC observed on oxygenation (Table 3 ) is significant for downstream water treatment as our previous work showed this has more environmental persistence than vegetation sources (Ritson et al., 2016), and the UV and fluorescence data suggested DOC from peat exposed to oxygen may be more difficult to remove by conventional treatment measures. High DOC production was noted for the vascular plants, suggesting they may be an important source of DOC within peatland catchments during the period of their senescence, although drought does not affect the amount they produce. Drought conditions may, however, precipitate a change in vegetation type favouring more drought-tolerant species (Bragazza, 2008), which may have longer-term effects for peatland biogeochemistry.

Correlations between litter $\mathrm{C}: \mathrm{N}$ ratio, suggesting nutrient availability, and amount of water-extractable DOC have been found in our previous work (Ritson et al., 2016) and elsewhere in the literature (Soong et al., 2014), suggesting a shift to the drought-tolerant Molinia and Juncus may increase DOC flux from the litter layer.

\subsection{SUVA and fluorescence}

The SUVA value has been linked to the aromaticity of DOM (Weishaar et al., 2003) and is of interest as a predictor of coagulation removal efficiency and DBP formation (Matilainen et al., 2011) in water treatment. The highest SUVA value was observed for the peat soil and Molinia litter, and the lowest value for the statistical subset of Sphagnum and Calluna. In a similar trend to DOM production, it appears that the grassland species produce DOM of greater aromaticity than the peatland species. Molinia also showed an interactive effect with the drought treatment, with a greater flux of aromatic compounds at the moderate and severe treatments, suggesting dry conditions are favourable for the breakdown and/or solubilisation of aromatic compounds in Molinia litter. Molinia DOM may, therefore, contribute to the increase in the aromaticity of peatland DOC observed after droughts at the catchment scale (Scott et al., 1998; Watts et al., 2001), although solubility controls on peat-derived DOM may be more important (Clark et al., 2006, 2005; Clark et al., 2011).

No drought effect was found for the SUVA value of peat, which is in contrast to field studies which have shown a decrease in aromaticity of DOM during drought due to solubility controls and an increase in aromaticity on rewetting (Evans et al., 2005; Scott et al., 1998; Watts et al., 2001; Worrall et al., 2004). This may be explained by the fact that field studies have shown an increase in DOM aromaticity over many years, whereas this study examined a single rewetting event following drought, so the altered biogeochemical controls on DOM aromaticity may not have had enough time to exert a significant effect. Comparing our results to field findings, then, suggests that a sharp pulse in high-aromaticity DOM on rewetting is unlikely but that elevated amounts may be present over longer timescales. The laboratory conditions may also have played a part, as the control sample is likely to have been exposed to more oxygenation through sample collection and setup of the experiment than undisturbed peat in the field, therefore increasing its similarity to the treatment conditions. The changes in DOM properties when the control group was repeated would appear to confirm this hypothesis.

A drought effect was observed for peak $\mathrm{C}$ (Juncus and Molinia) and peak T (Juncus) with lower values under severe drought. These indices have been described as "humic-like" and "protein-like", respectively; however meaningful interpretation of the moieties responsible is difficult as many compounds can fluoresce in these regions (Aiken, 2014). From Table 2, however, we can suggest that decreases in peak $\mathrm{C}$ caused by drought may decrease the amenability of DOC to removal by coagulation.

Taken together, the main effects and interaction and $\omega^{2}$ values suggest that the source of DOM is the most important factor on SUVA and fluorescence and that the effect of drought is significant only for Molinia and Juncus litter and not for the other vegetation types or the peat soil. These results suggest encroachment of grassland species into the uplands will increase seasonal DOM flux from the litter layer, increase the aromaticity of exported DOM and create a small drought effect where Molinia or Juncus litter is present. The lack of a drought effect for peat SUVA suggests that short pulses of highly aromatic DOM are unlikely to be observed, but long-term effects caused by water table drawdown identified elsewhere in the literature indicate elevated DOC concentration and SUVA values over periods of years following droughts. The effect of more frequent, repeated droughts and the ability of peat soils to recover remains an area for further research.

\subsection{DOC and SUVA removal}

DOC removal for all sources was typical of literature values (Matilainen et al., 2010), with Juncus DOC proving the easiest to remove and Sphagnum DOC the hardest. Sphagnum DOC showed good removal of SUVA despite relatively poor removal of total DOC, suggesting the aromatic compounds present in the sample are easily removed but that a large pool of aliphatic compounds are also present, and these are more difficult to treat by conventional means. Repeating the control condition and measuring DOC production and quality parameters allowed an estimate of the effect of oxygen exposure for peat samples. This showed a decrease in SUVA value and humic-like character (fluorescence 
peak C) as well as a large increase in water-extractable DOC. These changes in quality parameters may provide an explanation of why poorer removal by coagulation was achieved for peat following this drought experiment than had been observed in our previous work (Ritson et al., 2016). In Ritson et al. (2016), coagulation experiments were performed on DOC extracted from fresh peat which had been exposed to a minimal amount of oxygenation during transport, and very good removal by coagulation/flocculation was found. In contrast, the experiments reported here on peat exposed to oxygen showed comparatively poor removal via coagulation/flocculation. The repetition of the control group indicates that any exposure to oxygenation can decrease the SUVA and peak-C values of DOC extracted from peat, and both of these parameters have been linked to ease of treatability of DOC (Matilainen et al., 2011). Poorer removal was observed for Sphagnum than in our previous work; the effect of more oxygenated conditions on vegetation decomposition remains an area for further research, particularly as climate change may increase the likelihood of water table drawdown in peatlands.

The coagulation removal efficiency could best be explained by the peak-C fluorescence index, suggesting humic substances content was the strongest predictor of DOC removal. This is in contrast to our previous work which found the ratio of humic-like to protein-like DOC to be the most important predictor (Ritson et al., 2014b). Our previous work used DOC collected throughout a two-month simulation rather than a single rewetting event at the end. The samples will, therefore, have likely undergone microbial processing during this simulation and consequently an increase in the amount of autochthonous DOM - hence the greater importance of the fluorescence measure of protein-like DOM.

\section{Conclusions}

Climate projections for the UK vary; however most agree the likelihood of droughts in the future is set to increase. The results of this research suggest the dominant effect of drought on peatland DOC sources is to increase the amount and decrease the treatability of DOC from peat soils. This is likely due to the enzymatic-latch mechanism increasing decomposition when oxic conditions prevail. No drought effect on the amount of DOC from different vegetation litters was found, although an increase in SUVA value from Molinia DOC was observed and could offset decreases in peat DOC. The greatest effect of drought for vegetation may be facilitating shifts to drought-tolerant species dominance rather than altering decomposition processes in the short term. Oxygenation of peat appears to greatly increase water-extractable DOM, and whilst no drought effect was observed, extracts before and after oxygenations showed decreased aromaticity and humification, which may mean it is more difficult to remove at the treatment works. These results provide support for catchment management programmes seeking to increase resilience to drought by raising peatland water tables as a strategy for mitigating against high riverine DOC concentrations following droughts.

Data availability. Raw data can be found in the Supplement.

\section{The Supplement related to this article is available online at https://doi.org/10.5194/bg-14-2891-2017-supplement.}

Author contributions. All authors developed the experimental design and advised on the subsequent analysis. JPR performed the experiments and data analysis. The manuscript was written by JPR with contributions from all co-authors.

Competing interests. The authors declare that they have no conflict of interest.

Acknowledgements. This work was supported by the Engineering and Physical Sciences Research Council (grant number EP/N010124/1). The authors would also like to thank the Grantham Institute: Climate and Environment and Climate-KIC for the financial support of Jonathan Ritson. The authors would also like to thank South West Water's Mires project for access to sites as well as Exmoor and Dartmoor National Park Authorities, Natural England and the Duchy of Cornwall. Chris Freeman acknowledges NERC grant NE/K01093X/1.

Edited by: Peter van Bodegom

Reviewed by: three anonymous referees

\section{References}

Aerts, R.: Interspecific competition in natural plant communities: mechanisms, trade-offs and plant-soil feedbacks, J. Exp. Bot., 50, 29-37, 1999.

Aiken, G.: Fluorescence and dissolved organic matter: A chemist's persepctive, in: Aquatic organic matter fluorescence, edited by: Coble, P. G., Lead, J., Baker, A., Reynolds, D., and Spencer, R. G. M., 35-74, Cambridge University Press, 2014.

Arnott, S.: Exmoor Hydrological and Hydrogeological monitoring plan for the Mires-on-the-Moors project, Environment Agency, Exeter, UK, 2010.

Beggs, K. M. H., Billica, J. A., Korak, J. A., Rosario-Ortiz, F. L., McKnight, D. M., and Summers, R. S.: Spectral evaluation of watershed DOM and DBP precursors, J. Am. Water Works Ass., 105, E173-E188, https://doi.org/10.5942/jawwa.2013.105.0063, 2013.

Berendse, F.: Litter decomposability - a neglected component of plant fitness, J. Ecol., 82, 187-190, 1994.

Berendse, F., Van Breemen, N., Rydin, H., Buttler, A., Heijmans, M., Hoosbeek, M. R., Lee, J. A., Mitchell, E., Saarinen, T., 
Vasander, H., and Wallén, B.: Raised atmospheric $\mathrm{CO}_{2}$ levels and increased $\mathrm{N}$ deposition cause shifts in plant species composition and production in Sphagnum bogs, Glob. Change Biol., 7, 591-598, 2001.

Billett, M. F., Charman, D. J., Clark, J. M., Evans, C. D., Evans, M. G., Ostle, N. J., Worrall, F., Burden, A., Dinsmore, K. J., Jones, T., McNamara, N. P., Parry, L., Rowson, J. G., and Rose, R.: Carbon balance of UK peatlands: current state of knowledge and future research challenges, Clim. Res., 45, 13-29, 2010.

Bond, T., Goslan, E. H., Parsons, S. A., and Jefferson, B.: Treatment of disinfection by-product precursors, Environ. Technol., 32, 125, https://doi.org/10.1080/09593330.2010.495138, 2011.

Box, G. and Cox, D.: An analysis of transformations, J. R. Stat. Soc. Ser. B, 26, 211-252, 1964.

Bragazza, L.: A climatic threshold triggers the die-off of peat mosses during an extreme heat wave, Glob. Change Biol., 14, 2688-2695, 2008.

Bragazza, L., Siffi, C., Iacumin, P., and Gerdol, R.: Mass loss and nutrient release during litter decay in peatland: The role of microbial adaptability to litter chemistry, Soil Biol. Biochem., 39, 257-267, https://doi.org/10.1016/j.soilbio.2006.07.014, 2007.

Chambers, F.: Recent rise to dominance of Molinia caerulea in environmentally sensitive areas: new perspectives from palaeoecological data, J. Appl., 44, 719-733, 1999.

Chambers, F., Mauquoy, D., Gent, A., Pearson, F., Daniell, J. R. G., and Jones, P. S.: Palaeoecology of degraded blanket mire in South Wales: Data to inform conservation management, Biol. Conserv., 137, 197-209, 2007a.

Chambers, F., Mauquoy, D., Cloutman, E. W., Daniell, J. R. G., and Jones, P. S.: Recent vegetation history of Drygarn Fawr (Elenydd SSSI), Cambrian Mountains, Wales: Implications for conservation management of degraded blanket mires, Biodivers. Conserv., 16, 2821-2846, 2007b.

Chantigny, M. H., Angers, D. A., Kaiser, K., and Kalbitz, K.: Extraction and characterisation of dissolved organic matter, in: Soil Sampling and Methods of Analysis, edited by: Carter, M. R. and Gregorich, E. G., 2nd Edn., Canadian Society of Soil Science, 2007

Clark, J., Chapman, P., Adamson, J., and Lane, S.: Influence of drought-induced acidification on the mobility of dissolved organic carbon in peat soils, Glob. Change Biol., 11, 791-809, 2005.

Clark, J., Chapman, P., Heathwaite, A., and Adamson, J.: Suppression of dissolved organic carbon by sulfate induced acidification during simulated droughts, Environ. Sci. Technol., 40, 17761783, 2006.

Clark, J., Gallego-Sala, A., Allott, T., Chapman, S., Farewell, T., Freeman, C., House, J., Orr, H., Prentice, I., and Smith, P.: Assessing the vulnerability of blanket peat to climate change using an ensemble of statistical bioclimatic envelope models, Clim. Res., 45, 131-150, 2010.

Clark, J. M., Heinemeyer, A., Martin, P., and Bottrell, S. H.: Processes controlling DOC in pore water during simulated drought cycles in six different UK peats, Biogeochemistry, 109, 253-270, 2011

Cole, L., Bardgett, R. D., Ineson, P., and Adamson, J. K.: Relationships between enchytraeid worms (Oligochaeta), climate change, and the release of dissolved organic carbon from blanket peat in northern England, Soil Biol. Biochem., 34, 599-607, 2002.
Cortez, J., Demard, J. M., Bottner, P., and Jocteur Monrozier, L.: Decomposition of mediterranean leaf litters: A microcosm experiment investigating relationships between decomposition rates and litter quality, Soil Biol. Biochem., 28, 443-452, 1996.

Dickinson, C. and Maggs, G.: Aspects of the decomposition of Sphagnum leaves in an ombrophilous mire, New Phytol., 73, 1249-1257, 1974.

Dinsmore, K. J., Billett, M. F., Skiba, U. M., Rees, R. M., Drewer, J., and Helfter, C.: Role of the aquatic pathway in the carbon and greenhouse gas budgets of a peatland catchment, Glob. Change Biol., 16, 2750-2762, 2010.

Don, A. and Kalbitz, K.: Amounts and degradability of dissolved organic carbon from foliar litter at different decomposition stages, Soil Biol. Biochem., 37, 2171-2179, 2005.

Evans, C. D., Monteith, D. T., and Cooper, D. M.: Long-term increases in surface water dissolved organic carbon: observations, possible causes and environmental impacts, Environ. Pollut., 137, 55-71, 2005.

Evans, M. G. and Warburton, J.: Peatland Geomorphology and Carbon Cycling, Geogr. Compass, 4, 1513-1531, 2010.

Fellman, J. B., Petrone, K. C., and Grierson, P. F.: Leaf litter age, chemical quality, and photodegradation control the fate of leachate dissolved organic matter in a dryland river, J. Arid Environ., 89, 30-37, https://doi.org/10.1016/j.jaridenv.2012.10.011, 2013.

Fenner, N. and Freeman, C.: Drought-induced carbon loss in peatlands, Nat. Geosci., 4, 895-900, 2011.

Fenner, N., Ostle, N. J., McNamara, N., Sparks, T., Harmens, H., Reynolds, B., and Freeman, C.: Elevated $\mathrm{CO}_{2}$ Effects on Peatland Plant Community Carbon Dynamics and DOC Production, Ecosystems, 10, 635-647, 2007.

Freeman, C., Ostle, N., and Kang, H.: An enzymic "latch" on a global carbon store, Nature, 409, p. 149, 2001.

Gallego-Sala, A. V. and Prentice, I. C.: Blanket peat biome endangered by climate change, Nat. Clim. Chang., 3, 152-155, 2012.

Gogo, S., Laggoun-Défarge, F., Delarue, F., and Lottier, N.: Invasion of a Sphagnum-peatland by Betula spp and Molinia caerulea impacts organic matter biochemistry. Implications for carbon and nutrient cycling, Biogeochemistry, 106), 53-69, 2010.

Gough, R., Holliman, P., Willis, N., Jones, T., and Freeman, C.: Influence of habitat on the quantity and composition of leachable carbon in the $\mathrm{O}_{2}$ horizon: Potential implications for potable water treatment, Lake Reserv. Manage., 28, 282-292, 2012.

Grand-Clement, E., Anderson, K., Smith, D., Luscombe, D., Gatis, N., Ross, M., and Brazier, R. E.: Evaluating ecosystem goods and services after restoration of marginal upland peatlands in SouthWest England, J. Appl. Ecol., 50, 324-334, 2013.

Holm, S.: A simple sequentially rejective multiple test procedure, Scand. J. Stat., 6, 65-70, 1979.

Howson, G., Howard, D. M., and Scott, W. A.: Long term study of litter decomposition on a Pennine peat bog: which regression?, Oecologia, 113, 94-103, 1998.

Jenkins, G., Murphy, J., Sexton, D., Lowe, J., Jones, P., and Kilsby, C.: UK climate projections: briefing report, Met Office, Exeter, UK, 2009.

Keselman, H.: A Monte Carlo investigation of three estimates of treatment magnitude: Epsilon squared, eta squared, and omega squared, Can. Psychol. Rev., 16, 44-48, 1975. 
Lapworth, D. J. and Kinniburgh, D. G.: An R script for visualising and analysing fluorescence excitation-emission matrices (EEMs), Comput. Geosci., 35, 2160-2163, 2009.

Latter, P. M., Howson, G., Howard, D. M., and Scott, W. A.: Longterm study of litter decomposition on a Pennine peat bog: which regression?, Oecologia, 113, 94-103, 1998.

Lawaetz, A. J. and Stedmon, C. A.: Fluorescence intensity calibration using the Raman scatter peak of water, Appl. Spectrosc., 63, 936-940, 2009.

Lazenby, A.: Germination and establishment of Juncus effusus L.: II. The interaction effects of moisture and competition, J. Ecol., 43, 595-605, 1955.

Levene, H.: Robust tests for equality of variances, in: Contributions to Probability and Statistics: Essays in Honor of Harold Hotelling, 278-292, Stanford University Press, 1960.

Limpens, J., Berendse, F., Blodau, C., Canadell, J. G., Freeman, C., Holden, J., Roulet, N., Rydin, H., and Schaepman-Strub, G.: Peatlands and the carbon cycle: from local processes to global implications - a synthesis, Biogeosciences, 5, 1475-1491, https://doi.org/10.5194/bg-5-1475-2008, 2008

Loach, K.: Seasonal Growth and Nutrient Uptake in a Molinietum, J. Ecol., 56, 433-444, 1968.

Luscombe, D., Smith, D., Grand-Clement, E., and Brazier, R.: Initial changes in hydrology and water quality following restoration of a shallow degraded peatland in the South West, in: Water@Leeds Upland Hydrology Meeting, available at: http://www.uplandhydrology.org.uk/05-initial-changesin-hydrology-and-water-quality-following-restoration-of-ashallow-degraded-peatland-in-the-south-west/ (last access: 15 June 2017), 2014.

Matilainen, A., Vepsäläinen, M., and Sillanpää, M.: Natural organic matter removal by coagulation during drinking water treatment: a review, Adv. Colloid Interfac., 159, 189-197, 2010.

Matilainen, A., Gjessing, E. T., Lahtinen, T., Hed, L., Bhatnagar, A., and Sillanpää, M.: An overview of the methods used in the characterisation of natural organic matter (NOM) in relation to drinking water treatment, Chemosphere, 83, 1431-1444, 2011.

McCorry, M. J. and Renou, F.: Ecology and management of Juncus effusus (soft rush) on cutaway peatlands, For. Ecosyst. Res. Gr. Rep. Number 69, Dublin, Ireland, 2003.

Nieuwenhuijsen, M. J., Grellier, J., Smith, R., Iszatt, N., Bennett, J., Best, N., and Toledano, M.: The epidemiology and possible mechanisms of disinfection by-products in drinking water, Philos. T. R. Soc. A., 367, 4043-4076, 2009.

Reckhow, D., Rees, P., Nüsslein, K., Makdissy, G., Devine, G., Conneely, T., Boutin, A., and Bryan, D.: Long-term Variability of BDOM and NOM as Precursors in Watershed Sources, AwwaRF, Denver, CO, 2007.

Ritson, J., Bell, M., Graham, N. J. D., Templeton, M. R., Brazier, R. E., Verhoef, A., Freeman, C., and Clark, J. M.: Simulated climate change impact on summer dissolved organic carbon release from peat and surface vegetation: Implications for drinking water treatment, Water Res., 67, 66-76, 2014a.

Ritson, J., Graham, N., Templeton, M. R., Clark, J. M., Gough, R., and Freeman, C.: The impact of climate change on the treatability of dissolved organic matter (DOM) in upland water supplies: A UK perspective, Sci. Total Environ., 473-474, 714-730, 2014 b.

Ritson, J. P., Bell, M., Brazier, R. E., Grand-clement, E., Graham, N. J. D., Freeman, C., Smith, D., Templeton, M. R., and Clark, J.
M.: Managing peatland vegetation for drinking water treatment, Sci. Rep., 6, 36751, https://doi.org/10.1038/srep36751, 2016.

Rodriguez, M. J. and Sérodes, J. B.: Spatial and temporal evolution of trihalomethanes in three water distribution systems, Water Res., 35, 1572-1586, 2001.

Rook, J. J.: Formation of haloforms during chlorination of natural water, Water Treat. Exam., 23, 234-243, 1974.

Scott, M., Jones, M., Woof, C., and Tipping, E.: Concentrations and fluxes of dissolved organic carbon in drainage water from an upland peat system, Environ. Int., 24, 537-546, 1998.

Shaw, S. C., Wheeler, B. D., Kirby, P., Philipson, P., and Edmunds, R.: Literature review of the historical effects of burning and grazing of blanket bog and upland wet heath, English Nature Research Reports and Countryside Council for Wales, English Nat. Res. Rep. 172, 1996.

Šidák, Z.: Rectangular Confidence Regions for the Means of Multivariate Normal Distributions, J. Am. Stat. Assoc., 62, 626-633, 1967.

Smith, D.M., Barrowclough, C., Glendinning, A. D., and Hand, A.: Exmoor Mires Project : Initial analyses of post restoration vegetation monitoring data, in: In the Bog, 1-18, available at: http://www.southwestwater.co.uk/media/pdf/g/q/ Exmoor_Mires_Project_Initial_analyses_of_post_restoration_ vegetation_monitoring_data_Smith_D._et_a.pdf (last access: 15 June 2017), 2014.

Soong, J. L., Calderón, F. J., Betzen, J., and Cotrufo, M. F.: Quantification and FTIR characterization of dissolved organic carbon and total dissolved nitrogen leached from litter: a comparison of methods across litter types, Plant Soil, 385, 125-137, 2014.

Soong, J. L., Parton, W. J., Calderon, F., Campbell, E. E., and Cotrufo, M. F.: A new conceptual model on the fate and controls of fresh and pyrolized plant litter decomposition, Biogeochemistry, 124, 27-44, https://doi.org/10.1007/s10533-0150079-2, 2015.

Spaccini, R., Piccolo, A., and Conte, P.: Increased soil organic carbon sequestration through hydrophobic protection by humic substances, Soil Biol. Biochem., 34, 1839-1851, 2002.

Spearman, C.: The Proof and Measurement of Association between Two Things, Am. J. Psychol., 15, 72-101, 1904.

Student, A.: The probable error of a mean, Biometrika, 6, 1-25, 1908.

Tang, R., Clark, J. M., Bond, T., Graham, N., Hughes, D., and Freeman, C.: Assessment of potential climate change impacts on peatland dissolved organic carbon release and drinking water treatment from laboratory experiments, Environ. Pollut., 173, 270-277, 2013.

Toberman, H., Freeman, C., Artz, R. R. E., Evans, C. D., and Fenner, N.: Impeded drainage stimulates extracellular phenol oxidase activity in riparian peat cores, Soil Use Manage., 24, 357365, 2008.

van Breemen, N.: How Sphagnum bogs down other plants, Trends Ecol. Evol., 10, 270-275, 1995.

Van Meeteren, M. J. M., Tietema, A., and Westerveld, J. W.: Regulation of microbial carbon, nitrogen, and phosphorus transformations by temperature and moisture during decomposition of Calluna vulgaris litter, Biol. Fertil. Soils, 44, 103-112, 2007.

Watts, C. D., Naden, P. S., Machell, J., and Banks, J.: Long term variation in water colour from Yorkshire catchments, Sci. Total Environ., 278, 57-72, 2001. 
Weishaar, J. L., Aiken, G. R., Bergamaschi, B. A., Fram, M. S., Fujii, R., and Mopper, K.: Evaluation of specific ultraviolet absorbance as an indicator of the chemical composition and reactivity of dissolved organic carbon, Environ. Sci. Technol., 37, 47024708, 2003.

Weltzin, J. F., Bridgham, S. D., Pastor, J., Chen, J., and Harth, C.: Potential effects of warming and drying on peatland plant community composition, Glob. Change Biol., 9, 141-151, 2003.

Worrall, F. and Burt, T.: Time series analysis of long-term river dissolved organic carbon records, Hydrol. Process., 18, 893-911, 2004.
Worrall, F., Burt, T., and Shedden, R.: Long term records of riverine dissolved organic matter, Biogeochemistry, 64, 165-178, 2003.

Worrall, F., Harriman, R., Evans, C. D., Watts, C. D., Adamson, J., Neal, C., Tipping, E., Burt, T., Grieve, I., Monteith, D., Naden, P. S., Nisbet, T., Reynolds, B., and Stevens, P.: Trends in Dissolved Organic Carbon in UK Rivers and Lakes, Biogeochemistry, 70, 369-402, 2004. 